Edward, D. G. FF. \& Freundt, E. A. (1956). J. gen. Microbiol. 14, 197-207

\title{
The Classification and Nomenclature of Organisms of the Pleuropneumonia Group
}

\author{
BY D. G. FF. EDWARD \\ The Wellcome Research Laboratories, Beckenham, Kent \\ AND E. A. FREUNDT \\ Statens Seruminstitut, Copenhagen
}

The taxonomic status of the micro-organisms of the pleuropneumonia group has remained confused for many years. There is no generally accepted nomenclature or classification, although the need for these has been widely recognized and has become more urgent with the increasing number of new strains of pleuropneumonia-like organisms isolated. Recently Freundt (1955) and Edward (1955) made proposals for classifying and naming these organisms. Although published separately their proposals were in close agreement with each other, as a result of previous informal exchanges of views between the authors. However, it was felt that the publication of two separate papers, each of which provided lists of named species differing from each other only slightly, might cause confusion, particularly as both papers unfortunately contained a number of printing errors. Therefore, it was decided to prepare a joint paper. It is hoped that the proposals made will provide a basis for discussion among those interested in this group of organisms, and will lead to the adoption of a nomenclature which commands general agreement. It is also felt that the study of strains of pleuropneumonia-like organisms may be stimulated by the establishment of named species.

\section{GENERAL RELATIONSHIPS}

\section{Relation to bacteria}

The relation of the pleuropneumonia-like organisms to bacteria (Schizomycetes) requires special consideration because of its fundamental taxonomic importance. In this connexion particular attention must be paid to morphology and mode of reproduction. Unfortunately there is still considerable disagreement among workers who have studied these properties. Some authors (Ørskov, 1927, $1942 b$; Freundt, 1952a, 1954) have described a mycelial mode of growth occurring under optimal culture conditions with multiplication by the formation in the filaments of minute endomycelial corpuscles which are subsequently released as free elementary bodies. This method of reproduction has certain features in common with that of some Actinomyces spp. The pleuropneumonialike organisms also resemble the actinomycetes in the way their colonies grow into the media. If this interpretation of morphology and method of reproduction, which dates back to the earliest investigations of the organisms (for references see Freundt, 1952a), were generally accepted it would warrant 
the classification of the pleuropneumonia group of organisms as a true bacterial order, parallel with, but not actually phylogenetically related to, Actinomycetales.

Reproduction by other methods has, however, been described. Keller \& Morton (1954) and Butler \& Knight (1956), using turbidimetric and viable count methods, demonstrated a normal bacterial growth cycle with strains of pleuropneumonia-like organisms, thus suggesting growth by simple binary fission. A quite different method of multiplication has been claimed by Klieneberger-Nobel (1954) and Dienes \& Weinberger (1951), who believed that small granules multiply within the cytoplasm of large, round cells; after rupture of the surrounding membrane these granules develop into large cells and repeat the life cycle. The L-phase variants of bacteria were believed to multiply in a similar manner (Dienes \& Weinberger, 1951; Tulasne, 1951). Reproduction by budding, similarly to yeasts, has also been claimed for pleuropneumonia-like organisms (Turner, 1935).

The cytoplasm of true bacteria is enclosed within a definite, more or less rigid, cell wall, but the elementary bodies and filaments of pleuropneumonialike organisms are bounded only by a delicate membrane; the organisms are thus extremely plastic and easily ruptured or distorted by mechanical influences, such as changes in osmotic pressure. Although this cytological difference between pleuropneumonia-like organisms and bacteria is obviously important, further studies, particularly in regard to the physiological functions which are linked with the cell surface, are required before its significance can be fully evaluated.

The study of the metabolic behaviour of the pleuropneumonia-like organisms is still in its infancy, although remarkable progress has been made in recent years and a number of differences shown between pleuropneumonia-like organisms and bacteria. Pleuropneumonia-like organisms exhibit a greater resistance to a number of bacteriostatic substances. For instance, they will resist concentrations of crystal violet which inhibit Gram-positive bacteria and will alsogrow in concentrations of potassium tellurite which are inhibitory for Gramnegative bacteria (Edward, 1947; Smith, Morton \& Leberman, 1950). Probably of greater importance is the absolute resistance to penicillin, independent of the action of penicillinase. Cholesterol, or certain other sterols, is an essential nutrient for pleuropneumonia-like organisms, with the possible exception of the saprophytic strains (Edward \& Fitzgerald, 1951b). Media that have not been enriched with serum permit the growth of the saprophytic strains, but are likely to contain small amounts of sterol. The possibility of growing the strains in strictly sterol-free media has not been investigated. The finding that cholesterol is a growth factor would seem to be particularly significant, for sterols have not been found to be essential for the growth of bacteria, even in their L-phase. The value of a difference in an essential growth factor in distinguishing between large groups of micro-organisms has been recognized previously; Knight (1955) noted that $m$-inositol is required as a nutrient by many eumycetes, whereas it has never been found to be required as a nutrient by any schizomycete. 
The growth of pleuropneumonia-like organisms can be inhibited by incorporation of an antiserum in the culture medium; complement is not concerned in this inhibition. Although growth of Leptospira spp. is inhibited by antisera, no other bacterium is known to be inhibited in a similar way. Analogies have been drawn between this type of inhibition and neutralization of viruses by antibody (Edward \& Fitzgerald, 1954).

To conclude, obvious differences exist between pleuropneumonia-like organisms and bacteria. Sabin (1941a), Edward (1954) and KlienebergerNobel (1954) in their reviews of the organisms of the pleuropneumonia group regarded these differences as being sufficiently great to warrant classifying them separately from both bacteria and viruses. However, the taxonomic significance of these differences is still largely a matter of opinion, and every worker may not agree that the evidence is sufficient to exclude the pleuropneumonia-like organisms from the Schizomycetes. Final decisions must await further investigation.

\section{Relation to the L-phase variants of bacteria}

The disagreement regarding the relationship of organisms of the pleuropneumonia group to the $\mathrm{L}$-phase variants of bacteria has for many years been one of the major obstacles to any attempt to define and classify the group. Dienes \& Weinberger (1951) and Tulasne (1951) suggested that the pleuropneumonia-like organisms may have been derived from different bacteria through the formation of persistent L-phase variants. Such a view obviously excludes the possibility of classifying the organisms in a phylogenetically homogeneous group.

The similarities between organisms of the pleuropneumonia group and L-phase variants that have been advanced by those who adhere to this theory may be summarized as follows: an almost identical appearance of the colonies on solid media, morphological and physical similarity of the individual elements that make up the cultures, reproduction by swelling into large bodies and disintegration of these into granules, dependence on serum or ascitic fluid for growth and lack of sensitivity to penicillin.

In the experience of Ørskov (1942a), Klieneberger-Nobel (1954) and the present authors (Freundt, 1950; Edward, 1954), it is possible to distinguish L-phase colonies from those of organisms of the pleuropneumonia group, even on their gross appearance. A concrete example may illustrate this claim. Cultivation made by one of us (E.A.F.) from a submaxillary abscess of a rat yielded a mixed culture on solid medium comprising, amongst others, colonies of Streptobacillus moniliformis, together with two types of minute colony, one of which was at once regarded as the $\mathrm{L}$-phase of $S$. moniliformis $\left(\mathrm{L}_{1}\right)$, while the other was suspected to be a true pleuropneumonia-like organism. Further study of pure cultures proved this original conception to be correct. The ' $L_{1}$ ' colonies reverted to streptobacilli, while the other type was identified as Mycoplasma arthritidis ( $\mathrm{L}_{4}$ of Klieneberger).

This is not the place to describe the detailed morphology of the individual elements of the two groups of organisms or to discuss the interpretation of these 
features. It will be sufficient to draw attention to a few points only. The formation of elementary bodies in filamentous structures, as described above, which has been demonstrated by many workers with pleuropneumonia-like organisms, most recently by White, Wallace \& Alberts (1954) in electron micrographs of avian strains, has never been reported in L-phase cultures, although small filaments are eventually found in these. The significance of the large bodies in any comparison between the two groups of organisms depends on the interpretation reached regarding their true nature, and on this there is still fundamental and profound disagreement between various workers. It may be mentioned, however, that attempts to elucidate the nature of the large bodies by various experimental methods have failed to support the conception that the minute granules formed within them are viable elements; this was investigated for the L-phase variants by Freundt (1950) and Kellenberger, Liebermeister \& Bonifas (to be published) and for the pleuropnemonia-like organisms by Freundt (1952b), Keller \& Morton (1954) and Kellenberger et al. If the large bodies are largely degenerative in nature, as suggested by Ørskov $(1927,1942 a, b)$ and Freundt $(1950,1952 b)$, it is obvious that claims for a relationship between the pleuropneumonia-like organisms and L-phase variants of bacteria cannot be based upon them.

There appear to be important differences between organisms of the pleuropneumonia group and the L-phase of bacteria in metabolism and growthrequirements. Both pleuropneumonia-like organisms (except the saprophytic species) and the L-phase of Gram-negative bacteria required media enriched with a substance such as serum. For the former group of organisms the serum appears to act by supplying cholesterol which is an essential nutrient. Cholesterol, however, was not essential for the growth of two L-phase organisms (Edward, 1953). The L-phase of Proteus mirabilis has in fact been cultivated in a defined medium containing a mixture of amino acids (Medill \& O'Kane, 1954). The serum appears to promote the growth of this organism by neutralizing an inhibitor. It has been pointed out elsewhere that if pleuropneumonialike organisms had been derived from different bacteria it would be expected that their fermentative capacity for various carbohydrates would vary from organism to organism, whereas it has been found that all pleuropneumonialike organisms studied, if they ferment carbohydrates at all, ferment the same carbohydrates (Edward, 1954).

Recently Tulasne, one of the advocates of a close relationship between organisms of the pleuropneumonia group and L-phase variants, has in conjunction with Brisou (Tulasne \& Brisou, 1955) suggested a classification and nomenclature in which pleuropneumonia-like organisms without a proven derivation from bacteria are placed in one order, Pleuropneumoniales, and the L-phase variants of bacteria are assigned to a second order, Bactepneumoniales. Thus these workers agree to grouping organisms of the pleuropneumonia group proper, separately from the L-phase organisms. Although the nomenclature of the L-phase organisms will not be considered here the comment might be made that grouping together the L-phase variants of diverse bacteria into a completely new order would seem open to grave objection. 


\section{Relation to viruses}

Although the organisms of bovine pleuropneumonia and of agalactia were for many years regarded as viruses on account of their small dimensions, the pleuropneumonia-like organisms as a group are now generally regarded as distinct from the viruses. However, certain analogies with the viruses, although admittedly vague and merely suggestive, deserve mention.

Attention has been drawn previously (Edward, 1954) to an apparent resemblance in mode of reproduction, whereby filaments break up into elementary bodies, between pleuropneumonia-like organisms and influenza virus on the surface of infected cells (Wyckoff, 1953; Chu, Dawson \& Elford, 1949). Nevertheless, it would probably be unwise at present to attach too much importance to this similarity, because it is still obscure how this phenomenon is to be properly interpreted for the influenza virus. Present evidence suggests that the homogeneous and fragmented filaments observed on cells infected with influenza virus develop from, and are continuous with, the cytoplasm of the cells, and may be a cellular response to infection.

Sabin $(1941 a, b)$ emphasized the specificity of species of pleuropneumonialike organisms for particular hosts and used this as a basis for classification. This specificity appears to depend upon a very close relationship of the organisms when growing in vivo with certain host cells. Though perhaps not so definite and universal as suggested by Sabin, there is undoubtedly a tendency for specialized parasitic adaptation to the animal hosts which may be regarded as a distinctive feature, placing the pleuropneumonia group in this respect nearer to viruses than to most bacteria.

It was suggested by Lecce \& Morton (1954) that the characteristically slow growth of the organisms of the pleuropneumonia group and their relatively limited metabolic activity may from an evolutionary standpoint be regarded as a step in the direction of increased nutritional dependency. The validity of this view seems somewhat doubtful because recent investigations with improved methods suggest that the metabolic activity of the organisms is not so restricted as was hitherto imagined.

\section{TAXONOMIC UNITS}

\section{Type species}

It can hardly be doubted that the organism of bovine pleuropneumonia (basonym: Asterococcus mycoides) is to be preferred as the type species. It was the first to be isolated, has been studied the most and has already provided the name by which the organisms of the group have hitherto been known (pleuropneumonia-like organisms). The choice by Sabin (1941 $b$ ) of the organism of agalactia as the type species would have no advantage, and was in fact unfortunate, because its cultural properties had not then been firmly established (Edward, 1954). 


\section{Genus}

Contrary to Sabin $(1941 a, b)$, who suggested grouping the species of the pleuropneumonia group into several genera according to the animal hosts from which they were isolated, we feel that, at least provisonally, only one genus covering all the pleuropneumonia-like organisms should be recognized. The reasons for rejecting Sabin's system of genera based on host-parasite relationships were given in a previous paper (Edward, 1955). Differences in metabolic behaviour of pleuropneumonia-like organisms would seem to provide the soundest basis for distinguishing between genera, and future investigations may provide justification for setting up other genera later. It may be argued that the saprophytic strains should be assigned now to a second genus. The difference in growth requirements that would seem to justify this may, however, be only one of degree, for the organism of goat pleuropneumonia can grow to some extent without serum.

The name for the genus is determined by the first valid name applied to the type species. Asterococcus mycoides was the first binomial name given to the organism of bovine pleuropneumonia (Borrel, Dujardin-Beaumetz, Jeantet \& Jouan, 1910). While the specific epithet remains valid it was recently recognized by the Editorial Board of the International Bulletin of Bacteriological Nomenclature and Taxonomy (1955) that the generic name Asterococcus is illegitimate because it is a later homonym of the algal genus Asterococcus Scherffel (1908). The Editorial Board suggested two alternatives to replace Asterococcus: (1) Mycoplasma Nowak (1929), which was the first legitimate generic name given to the organism, and (2) Borrelomyces Turner (1935). The latter alternative was suggested on the assumption that it had already come into more general use among bacteriologists. This, however, is certainly not true, and there is nothing to justify the use of this name, which is the fourth in order of priority, in preference for one that has clear priority. Therefore it is proposed that Mycoplasma be conserved as the correct and legitimate generic name.

\section{FAMILY}

Only one family is recognized for the pleuropneumonia group. Sabin $(1941 a, b)$ proposed two families: Parasitaceae or Anulomycetaceae and Saprophytaceae or Sapromycetaceae. The reasons that were given above for classifying the parasitic and saprophytic species into a common genus may however be even more reasonably applied when speaking of the family.

The appropriate family name under the Rules, if Mycoplasma be accepted as the generic name, is Mycoplasmataceae.

\section{ORDER}

While Ledingham (1933), on morphological grounds, proposed that the organism of bovine pleuropneumonia and that of agalactia be incorporated in the existing order Actinomycetales, Turner (1935) was the first to realize that the properties of the group were sufficiently distinct to warrant the setting 
up of a new order within Schizomycetes. Sabin (1941 $a$ ) believed that the group differed fundamentally from bacteria and therefore assigned it to a separate class, Paramycetes, with one order.

The present authors agree that the organisms of the pleuropneumonia group differ so much from other micro-organisms that they cannot be incorporated into any existing order; they are thus assigned to a separate order. Since the relationship of the organisms to bacteria is uncertain, it seems wise to leave open for the moment the question whether this order should be included within the Schizomycetes. In the 6th edition of Bergey's Manual of Determinative Bacteriology (1948) the orders Virales and Rickettsiales are set up as separate groups whose relationships are uncertain. One of us (Edward, 1955) has suggested that the new order should be treated in the same way, as a third supplementary group.

The following names have been proposed for the order to include the organisms of the pleuropneumonia group:

1. Borrelomycetales Turner, 1935.

2. Paramycetales Sabin, 1941 $a$.

3. Anulomycetales Sabin, $1941 b$.

4. Pleuropneumoniales Tulasne \& Brisou, 1955.

5. Mycoplasmatales Freundt, 1955.

6. Mollicutales Edward, 1955.

Borrelomycetales has priority, and it was for this reason that Freundt (1955) suggested its conservation. However, there appears to be no clear statement in rules of nomenclature that the rule of priority is binding for names of orders. Borrelomycetales itself was derived from Borrelomyces, a generic name that is no longer regarded as legitimate; it would seem that there is no longer need to recognize the name derived from it for the order. The name was also rejected by Sabin (1941a), since Bordet and not Borrel was the first to describe the morphology of the pleuropneumonia organism. Moreover, -myces would possibly seem an unfortunate stem to use if in the future it be decided that the organisms should be placed in a group distinct from the Schizomycetes.

Paramycetales presupposes recognition of a new class, Paramycetes, and Sabin $(1941 b)$ later recognized its unsuitability as a name for the order and used Anulomycetales derived from Anulomyces agalaxiae. This name is also unsuitable since it is based upon an invalid generic name.

The proposal of Tulasne \& Brisou (1955) incorporates 'pleuropneumonia' which has provisionally come into general use to provide a comprehensive term for the group. However, it would be unfortunate, as previously pointed out (Edward, 1955), if this recent name, suggested during the course of informal discussion between workers in this field, should be perpetuated by reason of priority alone, since it is based on disease rather than on the organism itself; moreover, the vast majority of species within the order do not cause pleuropneumonia.

The amended Rules of Nomenclature state: 'Rule 2. Names of all taxonomic groups (taxa) above the rank of family are taken preferably from a 
combination of characters covering the nature of the taxa as closely as possible, or from a single character of outstanding importance. Recommendation: Names of orders and suborders may appropriately be based upon the name of a contained family.' An outstanding and possibly fundamental property of the pleuropneumonia-like organisms is their lack of a rigid cell wall. Mollicutales, based on this property, was therefore suggested as a name of the order. An alternative suggestion is Mycoplasmatales derived from the name of the family and thus fulfilling the recommendation in Rule 2 . In this way the introduction of a new name into the nomenclature of pleuropneumonia-like organisms is avoided. This name, too, is based on the plastic nature of the organisms. That Nowak (1929) when proposing Mycoplasma as the generic name intended to allude by this to the plasticity of the pleuropneumonia organism appears from his description: 'Le microbe semble, au mois à certains stades de son cycle évolutif, n'être qu'un petit amas de protoplasme à demi liquide, épais, d'une consistance homogène; il n'est donc pas différencié en exoplasme et endoplasme. Cette circonstance semble faciliter son polymorphisme' (p. 1348). Mycoplasmatales, however, is less preferable than Mollicutales as a descriptive term since it suggests a relationship with the fungi. It is proposed that Mollicutales and Mycoplasmatales be submitted for consideration as possible alternative names for the order.

\section{Established Species}

The selection of species to be included in the classification has been guided by the principle that for each species which is named and defined there should be kept in collections of type cultures a representative strain upon which the properties of that species have been based. Asterococcus I and II (Shoetensack, 1936), Musculomyces arthrotropicus and $M$. histotropicus (Sabin, 1941 a) set up earlier and based on strains which are no longer in existence have thus been omitted, because they cannot be definitely identified with any new isolates by reference to the original descriptions. Other strains of pleuropneumonia-like organisms that have been reported in recent years from various sources, e.g. from bronchopneumonia of cattle (Carter, 1954) and from the eyes of a chameleon (Klinge, 1954), need further study before they can be named as separate species.

The following tentative list of species is based on the lists previously published by each of us. The few points on which they deviated from each other have been adjusted. A new species, Mycoplasma hyorrhinis Switzer (1955), has been added. Strain numbers refer to the collection at the Wellcome Research Laboratories.

Order

Alternative 1. Mycoplasmatales, Freundt, 1955.

Alternative 2. Mollicutales, Edward, 1955.

Family

Genus
Mycoplasmataceae.

Mycoplasma, Nowak, 1929. 
The type species is Mycoplasma mycoides (Borrel et al.) Freundt.

Species 1. Mycoplasma mycoides (Borrel et al. 1910) Freundt.

Subspecies 1. Mycoplasma mucoides var. mycoides. Organism causing contagious pleuropneumonia of cattle. Representative strain: PG 1.

Subspecies 2. Mycoplasma mycoides var. capri (Edward, 1954) Freundt. Organism causing contagious pleuropneumonia and other infections in goats. Representative strain: PG 3.

Species. 2. Mycoplasma agalactiae (Wroblewski, 1931) Freundt. Organism causing contagious agalactia. Representative strain: PG 2.

Species 3. Mycoplasma bovigenitalium Freundt. $\mathbf{P}$ strains from cattle (Edward, 1950). Representative strain: PG 11.

Species 4. Mycoplasma spumans Edward. $\alpha$ strains from dogs (Edward \& Fitzgerald, 1951 a). Representative strain: PG 13.

Species 5. Mycoplasma canis Edward. $\beta$ strains from dogs (Edward \& Fitzgerald, 1951 a). Representative strain: PG 14. (Not Asterococcus canis Shoetensack, 1936.)

Species 6. Mycoplasma maculosum Edward. $\gamma$ strains from dogs (Edward \& Fitzgerald, 1951a). Representative strain: PG 15.

Species 7. Mycoplasma pulmonis (Sabin, 1941a) Freundt. L. 3 strains from rats (Klieneberger, 1938). Representative strain: 'Ash'.

Species 8. Mycoplasma arthritidis (Sabin, 1941a) Freundt. L. 4 strains from rats. Representative strain: 'Preston' (PG 6).

Species 9. Mycoplasma neurolyticum (Sabin, 1941a) Freundt. Type A and L. 5 strains from mice. Representative strain: L. 5 (PG 28).

Species 10. Mycoplasma gallinarum Freundt, 1955. Based on the cultural and biochemical examination of one strain (Edward, 1954). Relationship to strains isolated from chickens and turkeys by American and Canadian workers not yet established. Representative strain: PG 16.

Species 11. Mycoplasma hominis Edward, 1955.

Type 1. Human type 1 strains (Nicol \& Edward, 1953). Representative strain: PG 21.

Type 2. Human type 2 strains (Nicol \& Edward, 1953). Representative strain: $\mathrm{PG} \mathbf{2 7}$.

Species 12. Mycoplasma fermentans Edward, 1955. Human type 3 strains (Nicol \& Edward, 1953). Representative strain: PG 18.

Species 13. Mycoplasma salivarium Edward, 1955. Human type 4 strains (Nicol \& Edward 1953). Representative strain: PG 20.

Species 14. Mycoplasma laidlawii (Sabin, 1941a) Freundt. Sewage and other saprophytic strains. Representative strain: Sewage A (Laidlaw \& Elford, 1936), (PG 8). The specific epithet, laidlawi, suggested by Sabin has been altered to conform with the Rules for Bacteriological Nomenclature.

Species 15. Mycoplasma hyorrhinis (Switzer, 1955, nov. sp.). Organism causing a generalized infection in swine involving the serous membranes of the thoracic and abdominal cavities (Glasser's disease): Switzer (1953a,b). Representative strain: PG 29. 


\section{REFERENCES}

Bergey's Manual of Determinative Bacteriology (1948). Edited by Breed, R. S., Murray, E. G. D. \& Hitchens, A. P., 6th ed. London: Baillière, Tindall \& Cox. Borrel, Dujardin-Beaumetz, Jeantet \& Jouan (1910). Le microbe de la péripneumonie. Ann. Inst. Pasteur, 24, 168.

Butler, M. \& KNight, B. C. J. G. (1956). Growth curves of strains of pleuropneumonia-like organisms. J.gen. Microbiol. In the Press.

Carter, G. R. (1954). Pleuropneumonia-like organisms isolated from bronchopneumonia of cattle. Science, 120, 113.

Chu, C. M., Dawson, I. M. \& Elford, W. J. (1949). Filamentous forms associated with newly isolated influenza virus. Lancet, $\mathrm{i}, 602$.

Dienes, L. \& Weinberger, H. J. (1951). The L forms of bacteria. Bact. Rev. 15, 245.

EdtTorial Board (1955). The status and synonymy of the bacterial generic name Asterococcus. Int. Bull. Bact. Nomen. Taxon. 5, 13.

EDwARD, D. G. FF. (1947). A selective medium of pleuropneumonia-like organisms. J. gen. Microbiol. 1, 238.

EDward, D. G. FF. (1950). An investigation of pleuropneumonia-like organisms isolated from the bovine genital tract. J. gen. Microbiol. 4, 4.

Edward, D. G. FF. (1953). A difference in growth requirements between bacteria in the L-phase and organisms of the pleuropneumonia group. J.gen. Microbiol. $8,256$.

Edward, D. G. FF. (1954). The pleuropneumonia group of organisms: a review, together with some new observations. J. gen. Microbiol. 10, 27.

EDwARD, D. G. FF. (1955). A suggested classification and nomenclature for organisms of the pleuropneumonia group. Int. Bull. Bact. Nomen. Taxon. 5, 85.

Edward, D. G. FF. \& Fitzgerald, W. A. (1951 $a$ ). The isolation of organisms of the pleuropneumonia group from dogs. J. gen. Microbiol. 5, 566.

EDward, D. G. FF. \& Fitzgerald, W. A. $(1951 b)$. Cholesterol in the growth of organisms of the pleuropneumonia group. J. gen. Microbiol. 5, 576 .

EDward, D. G. FF. \& Fitzgerald, W. A. (1954). Inhibition of growth of pleuropneumonia-like organisms by antibody. J. Path. Bact. 68, 23.

Freundt, E. A. (1950). Observations on Dienes' L type growth of bacteria. Acta path. microbiol. scand. 27, 159.

Freundt, E. A. (1952a). Morphological studies of the peripneumonia organism (Micromyces peripneumoniae bovis). Acta path. microbiol. scand. 31, 508.

Freundt, E. A. (1952b). The nature of the 'large bodies' in the peripneumonia organism (Micromyces peripneumoniae bovis). Acta path. microbiol.scand.31, 561.

Freundt, E. A. (1954). Morphological and biochemical investigations of human pleuropneumonia-like organisms (Micromyces). Acta path. microbiol. scand. 34, 127.

Freundt, E. A. (1955). The classification of the pleuropneumonia group of organisms (Borrelomycetales). Int. Bull. Bact. Nomen. Taxon. 5, 67.

Keller, R. \& Morton, H. E. (1954). The growth of pleuropneumonia-like organisms of human origin: cultivation in the developing chick embryo and an in vitro growth cycle. J. Bact. 67, 129.

Kireneberger, E. (1938). Pleuropneumonia-like organisms of diverse provenance: some results of an enquiry into methods of differentiation. J. Hyg., Camb. 38, 458.

KLIENEBERger-Nobel, E. (1954). Micro-organisms of the pleuropneumonia group. Biol. Rev. 29, 154.

KLINGE, K. (1954). Über einen vom Chamäleon isolierten pleuropneumoniaähnlichen Mikroorganismus (PPLO). Archiv. Hyg., Berl. 138, 332.

KNIGHT, B. C. J. G. (1955). The principles of microbial classification. Nutritional characters. J. gen. Microbiol. 12, 348. 
Laidlaw, P. P. \& Elford, W. J. (1936). A new group of filterable organisms. Proc. Roy. Soc. B, 120, 292.

LECCE, J. G. \& Morton, H. E. (1954). Metabolic studies on three strains of pleuropneumonia-like organisms isolated from man. J. Bact. 67, 62.

Ledingham, J. C. G. (1933). The growth phases of pleuropneumonia and agalactia on liquid and solid media. J. Path. Bact., 37, 393.

Medill, M. A. \& O'Kane, D. J. (1954). A synthetic medium for the L-type colonies of Proteus. J. Bact. 68, 530.

Nicol, C. S. \& EDWARD, D. G. FF. (1953). Role of organisms of the pleuropneumonia group in human genital infections. Brit. J. vener. Dis. 29, 141.

Nowak, J. (1929). Morphologie, nature et cycle évolutif du microbe de la péripneumonie des bovidés. Ann. Inst. Pasteur, 43, 1330.

Orskov, J. (1927). Étude sur la morphologie du virus péripneumonique. Ann. Inst. Pasteur, 41, 473.

ØRsKov, J. (1942a). Streptobacillus moniliformis and the morphology of its variants. Acta path. microbiol. scand. 19, 575.

ØRSкоv, J. (1942b). On the morphology of peripneumonia-virus, agalactia-virus and Seiffert's microbes. Acta path. microbiol. scand. 19, 586.

SABIN, A. B. (1941 $a)$. The filtrable micro-organisms of the pleuropneumonia group. Bact. Rev. 5, 1.

Sabin, A. B. (1941 $b$ ). The filtrable micro-organisms of the pleuropneumonia group (Appendix on classification and nomenclature). Bact. Rev. 5, 331.

SchenfFel, A. (1908). Asterococcus n.g. superbus (Cienk.) Scherffel und dessen angebliche Beziehungen zu Eremosphaera. Ber. dtsch. bot. Ges. 26 A, 762.

Shoetensack, H. M. (1936). Pure cultivation of filtrable virus isolated from canine distemper (Part II). Morphological and cultural features of Asterococcus canis, type I, n.sp. and Asterococcus canis, Type II, n.sp. Kitasato Arch. 13, 175.

Smith, P. R., Morton, H. E. \& Leberman, P. R. (1950). Susceptibilities of pleuropneumonia-like organisms to some selective bacteriostatic agents. Proc. Soc. exp. Biol., N.Y. 74, 552.

SwItzer, W. P. $(1953 a)$. Studies on infectious atrophic rhinitis of swine. I. Isolation of a filterable agent from the nasal cavity of swine with infectious atrophic rhinitis. J. Amer. vet. med. Ass. 123, 45.

Switzer, W. P. $(1953 b)$. Studies on infectious atrophic rhinitis of swine. II. Intraperitoneal and intranasal inoculation of young pigs with a filterable agent isolated from nasal mucosa of swine. Vet. Med. 48, 392.

SwItzer, W. P. (1955). Studies on infectious atrophic rhinitis of swine. IV. Characterization of a pleuropneumonia-like organism isolated from the nasal cavities of swine. Amer. J. vet. Res. 16, 540.

Tulasne, R. (1951). Les formes L des bactéries. Rev. Immunol., Paris, 15, 223.

Tulasne, R. \& Brisou, J. (1955). Les pleuropneumoniales. Taxonomie des 'Pleuropneumonia-like organisms' et des formes L. Ann. Inst. Pasteur, 88, 237.

Turner, A. W. (1935). A study on the morphology and life cycles of the organism of Pleuropneumonia contagiosa boum (Borrelomyces peripneumoniae nov. gen.) by observation in the living state under dark-ground illumination. J. Path. Bact. 41, 1.

White, F. H., Wallace, G. I. \& Alberts, J. O. (1954). Serological and electron microscope studies of chronic respiratory disease agent of chickens and of turkey sinusitis agent. Poult. Sci. 33, 500.

Wroblewski, W. (1931). Morphologie et cycle évolutif des microbes de la péripneumonie des bovidés et de l'agalaxie contagieuse des chèvres et des moutons. Ann. Inst. Pasteur, 47, 94.

Wyckoff, R. G. W. (1953). Formation of the particles of influenza virus. J. Immunol. 70, 187.

(Received 1 September 1955) 